\title{
Identification of Plum pox virus Determinants Implicated in Specific Interactions with Different Prunus spp.
}

\author{
Sylvie Dallot, Laurence Quiot-Douine, Pilar Sáenz, Maria Teresa Cervera, \\ Juan-Antonio García, and Jean-Bernard Quiot
}

First, second, and sixth authors: Equipe virus-vecteur, ENSA-INRA, 2 place Viala, 34060 Montpellier cedex 1, France; and third, fourth, and fifth authors: Centro Nacional de Biotecnología, Campus de la Universidad Autónoma de Madrid, 28049 Spain.

Accepted for publication 17 October 2000.

\begin{abstract}
Dallot, S., Quiot-Douine, L., Sáenz, P., Cervera, M. T., García, J.-A., and Quiot, J.-B. 2001. Identification of Plum pox virus determinants implicated in specific interactions with different Prunus spp. Phytopathology 91:159-164.

The characterization of pathogenic properties of two infectious clones of Plum pox virus (PPV) isolates, pGPPV (D group) and pGPPVPS (M group), was investigated in their woody hosts (seedlings of Prunus spp.). The two clones differed in their ability to infect plum and peach cultivars, from no infection to local and systemic infection. The phenotype

determinants were located with a set of chimeric viruses from the two clones. In plum, determinants of systemic infection were located in a genomic fragment encoding the $\mathrm{P} 3$ and $6 \mathrm{~K} 1$ proteins, which might influence genome amplification or virus movement. The capacity of pGPPVPS to induce stable local and systemic infections in peach was not located accurately and might be influenced by multiple determinants carried by different regions of the genome, excluding those encoding the protein 1 , the majority of helper component, nuclear inclusions a and $b$, and coat protein. We conclude that PPV infections of plum and peach are governed by different determinants.
\end{abstract}

Plum pox virus (PPV) is the causal agent of Sharka, one of the most detrimental viral diseases of Prunus stone fruit crops in Europe and the Mediterranean Basin. It was also recently identified in Chile and the United States (16,30). The virus is transmitted by grafting and by aphids in a nonpersistent manner, inducing fast spreading epidemics, mainly in apricot, peach, and plum orchards.

PPV, a member of the genus Potyvirus, presents a singlestranded genomic RNA of approximately $10 \mathrm{~kb}$, translated into a large polyprotein, and subsequently processed by three virusencoded proteases into as many as 10 functional proteins $(24,26)$. Several serological and molecular tools, all based on the coat protein $(\mathrm{CP})$ coding region or the protein itself, have been developed for the characterization and typing of PPV populations. Using electro blot immunoassay, restriction fragment length polymorphism following polymerase chain reaction (PCR) amplification, monoclonal antibodies, and partial sequencing, results were positively correlated and indicated that most PPV isolates could be classified in two main groups, PPV-D and PPV-M (2,3). Atypical PPV-El Amar and cherry-adapted isolates have also been identified and assigned to groups distinct from PPV-D and PPV-M $(8,21,35)$.

Surveys of virus-infected trees in apricot and peach orchards showed distinct epidemic behaviors of PPV strains and isolates. Isolates of group $M$ have been associated with fast spreading outbreaks in peach orchards, whereas D populations are generally restricted to apricot trees. Moreover, several experiments using Prunus cultivars under controlled conditions confirmed these observations and led to the identification of some of the factors determining the competitiveness of PPV isolates on these hosts $(9,22)$.

Corresponding author: J.-B. Quiot; E-mail address: quiot@ensam.inra.fr

Publication no. P-2000-1113-01R

This article is in the public domain and not copyrightable. It may be freely reprinted with customary crediting of the source. The American Phytopathological Society, 2001.
Recently, significant advances have been made in understanding potyvirus pathogenesis. New molecular technologies have greatly helped in obtaining this knowledge, especially through the generation of infectious full-length cDNA clones, the construction of chimeric viruses, and the use of mutagenesis techniques. Determinants affecting genome amplification, cell-to-cell and longdistance movement, symptom expression, and aphid and seed transmissions have been identified for several Potyvirus spp. by these procedures $(24,26)$.

Infectious transcripts from full-length cDNAs produced in vitro or in vivo have been previously described for PPV isolates. The first were from the PPV-D group, PPV-NAT (18) and PPV-R (Rankovic isolate) (25), whereas Sáenz et al. (31) very recently described the construction of a cDNA clone of the PPV-PS isolate, a relative of the PPV-M group from which infectious transcripts can be made. Chimeric viruses from the parental full-length cDNA clones of PPV-R (pGPPV) and PPV-PS (pGPPVPS) were constructed and all transcripts were viable in Nicotiana clevelandii and Pisum sativum, allowing the first evaluation of symptom determinants of PPV on these herbaceous plants (31).

We utilized these parental and chimeric PPV clones to investigate viral sequences governing the pathogenesis of PPV on Prunus spp., its natural host, in the framework of the identification and understanding of the numerous factors determining the epidemiological properties of this virus.

\section{MATERIALS AND METHODS}

Clones and chimeric viruses. Infectious transcripts from fulllength cDNA clones of PPV-R (pGPPV) and PPV-PS (pGPPVPS) isolates were previously obtained, respectively, by Riechmann et al. (25) and Sáenz et al. (31). Current typing tools and sequence analysis assigned the PPV-R isolate to the PPV-D group and the PPV-PS isolate to the PPV-M group $(3,5,13)$. Progeny from these two clones, as well as up to 15 chimeric viruses whose construction was previously described by Sáenz et al. (31), were used in this study. 
Plant material. Initial assays were performed with progeny of infectious transcripts pGPPVPS and pGPPV and with a limited number of chimeric viruses in order to identify plant material and inoculation protocols appropriate for these virus sources. Commercially available juvenile seedlings obtained from virus-free seeds of distinct species of Prunus rootstocks were used in this study: peach, Prunus persica cvs. GF305 and Montclar; plum, Prunus insititia $\times$ Prunus domestica cv. St. Julien no. 2; and apricot, Prunus armeniaca cv. Manicot. We adopted a protocol of mechanical inoculation of the seedlings. This allowed us to simultaneously work with several chimeric viruses and multiple seedlings (a minimum of 10 seedlings for each virus source per experiment). Assays were repeated in order to limit the effect of possible genetic heterogeneity among these nonclonaly derived seedlings.

Inoculation of Prunus seedlings. Inoculum sources were obtained from Nicotiana benthamiana plants inoculated with the infectious transcripts. Systemically infected leaves, at 10 days postinoculation (dpi), were mixed and stored at $-80^{\circ} \mathrm{C}$ in order to use similar lots of inoculum for each experiment. Virus concentration in these samples was evaluated by double-antibody, sandwich enzyme-linked immunosorbent assay (DAS-ELISA). The first leaves of the juvenile virus-free seedlings (approximately 20 days after sowing) were dusted with Carborundum and inoculated mechanically with the crude sap extracts of infected Nicotiana benthamiana leaves diluted 10-fold in a phosphate solution $\left(0.03 \mathrm{M} \mathrm{Na} 2 \mathrm{H} \cdot \mathrm{PO}_{4}\right.$ containing $0.2 \%$ Na-diethyl dithiocarbamate).

The infectivity of the inoculum sources was determined by simultaneous inoculations of Nicotiana benthamiana and Pisum sativum plants. The plants were confined according to French safety regulations and kept in a growth chamber at a temperature of $25^{\circ} \mathrm{C} / 18^{\circ} \mathrm{C}$ (day/night) under fluorescent lamps (10,000 lux) with a 16-h/day photoperiod.

DAS-ELISA. The plants were individually tested for PPV infection by DAS-ELISA according to the procedure first described by Clark and Adams in 1977 (7) and optimized in the laboratory. Polysorp immunoplates (Nunc, Roskilde, Denmark) were coated with $1 \mu \mathrm{g} / \mathrm{ml}$ of purified antibodies from a broad reactivity antiPPV polyclonal rabbit antiserum (AS196) produced in the laboratory. Plant extracts were used at a 1:50 final dilution in phosphate-buffered saline with Tween plus $2 \%$ (wt/vol) polyvinylpyrrolidone (PVP) 40,000. Each sample was replicated in two contiguous wells, and healthy samples corresponding to the appropriate Prunus spp. were added at three replicates per plate. PPV-infected leaves of Nicotiana benthamiana were used as a positive control. The positive threshold was set at twice the mean of absorbance values $\left(A_{405}\right)$ obtained with the healthy samples. In some experiments, strain typing was also performed by western blot procedure as previously described (2) and by immunocapturereverse transcription-PCR $(2,34)$.

TABLE 1. Different pathogenic properties of Plum pox virus (PPV) isolates pGPPVPS and pGPPV progenies evaluated in seedlings of four Prunus cultivars $^{\mathrm{a}}$

\begin{tabular}{|c|c|c|c|c|c|c|c|c|}
\hline \multirow[b]{2}{*}{ Isolate } & \multicolumn{2}{|c|}{$\begin{array}{c}\text { Peach cv. } \\
\text { GF305 }\end{array}$} & \multicolumn{2}{|c|}{$\begin{array}{l}\text { Peach cv. } \\
\text { Montclar }\end{array}$} & \multicolumn{2}{|c|}{$\begin{array}{l}\text { Plum cv. St. } \\
\text { Julien no. } 2\end{array}$} & \multicolumn{2}{|c|}{$\begin{array}{l}\text { Apricot cv. } \\
\text { Manicot }\end{array}$} \\
\hline & $\mathrm{L}$ & S & $\mathrm{L}$ & S & $\mathrm{L}$ & S & $\mathrm{L}$ & S \\
\hline pGPPVPS & $9 / 20$ & $10 / 20$ & $13 / 20$ & $13 / 20$ & $3 / 23$ & $3 / 23$ & $3 / 25$ & $4 / 24$ \\
\hline pGPPV & $0 / 20$ & $0 / 20$ & $0 / 20$ & $0 / 20$ & $14 / 23$ & $0 / 23$ & $0 / 27$ & $0 / 27$ \\
\hline
\end{tabular}

a Juvenile seedlings of each cultivar were inoculated mechanically in two independent experiments. The presence of virus was determined by enzymelinked immunosorbent assay on extracts from the inoculated leaves at 20 days postinoculation ( $\mathrm{L}=$ local infection) and from young emerging leaves at 60 days postinoculation $(\mathrm{S}=$ systemic infection). The number of infected seedlings per inoculated seedlings are given.

\section{RESULTS}

Progeny of pGPPVPS and pGPPV clones express different pathogenic properties in three Prunus spp. Juvenile peach, plum, and apricot seedlings with five to seven fully expanded leaves were inoculated with pGPPVPS and pGPPV in two independent experiments (a minimum of 20 plants per virus and per Prunus cultivar was used). The presence of the virus in inoculated leaves at $20 \mathrm{dpi}$ and in newly developed leaves at 60 dpi was determined by DAS-ELISA.

The progeny of the two parental clones showed different pathogenic properties on the three Prunus spp. (Table 1). Progeny of pGPPVPS generated both local and systemic infections in all the four cultivars tested. On the contrary, pGPPV progeny induced obvious local infections in plum, but was not detected in the new upper leaves. For the two peach cultivars and apricot, local and systemic infections were never detected after inoculation with pGPPV progeny. In each case, control herbaceous plants simultaneously inoculated at the time of the tree inoculations became infected, confirming the infectivity of the inoculum sources.

These different pathogenic properties appeared as valid criteria and were further investigated with chimeric viruses. Further experiments were pursued with plum and peach cv. GF305 only, because the first assays with the parental clones gave identical results on the two peach cultivars. Unstable and low rates of infection on apricot were obtained by a first set of chimeric viruses, so no reliable conclusions could be drawn, and further experiments with this species were not pursued.

PPV sequences encoding the C-terminal of helper component, all of protein 3 , and the $\mathrm{N}$-terminal of protein $6 \mathrm{~K} 1$ are implicated in the systemic infection of plum. Up to 14 different chimeric viruses were used to locate the pathogenic properties on the PPV genome. Plum seedlings were mechanically inoculated in two independent experiments. Local and systemic infections were followed by sequential ELISA tests performed on extracts from the inoculated leaves at $20 \mathrm{dpi}$ and on newly emerged upper leaves at 60 and $160 \mathrm{dpi}$.

All chimeric viruses produced local infections, but only some of them induced systemic infections on this host. These two phenotypes were analogous to those observed with the parental clones. The results obtained with seven of the most relevant chimeric viruses are shown in Figure 1A. The introduction of pGPPV fragments, including those encoding protein 1 (P1) and most of helper component (HC) alone (pR/P2212) or with most of nuclear inclusion $b(\mathrm{Nib})$ and $\mathrm{CP}$ (pR/P2212-7677), into the pGPPVPS genome yielded progeny that induced local infections with a frequency similar to pGPPV. However, this did not modify the phenotype of systemic infection of pGPPVPS progeny. The induction of stable systemic infections by these chimeric viruses highlighted the importance of the central region of the PPV genome for this function.

The other chimeric viruses allowed us to more accurately map the sequences involved in systemic infection. The 2212-5535 and 2212-3628 pGPPV fragments (pP/R2212-5535 and pP/R22123628) conferred a pGPPV phenotype to pGPPVPS, thus restricting the virus to the inoculated leaves. As expected, progeny of the reciprocal clone pR/P2212-3628 were detected in the upper noninoculated leaves, demonstrating that the sequences required to induce systemic infections in this plum cultivar are located between nucleotides 2212 and 3628 of the viral sequence. The behavior of the other chimeric viruses tested was consistent with this result. This region of the viral genome encodes the $\mathrm{C}$-terminal region of $\mathrm{HC}, \mathrm{P} 3$, and $6 \mathrm{~K} 1$ proteins. The region of the PPV genome implicated in this phenotype codes for 473 amino acids, differing at 20 positions between PPV-R and PPV-PS (Fig. 2).

Results with two chimeric viruses (pR/P2212-2904 and $\mathrm{pR} / \mathrm{P} 2904-3628)$ containing smaller portions of pGPPVPS in this region did not allow us to more accurately determine the sequences responsible for this phenotype, because each was suffi- 
cient to induce a systemic infection. However, the frequency of systemic infection was greatly decreased when only the 2212-2904 pGPPVPS fragment was present. The estimation by DAS-ELISA of the virus titer in the inoculated leaves revealed a significantly lower accumulation of pR/P2212-2904 progeny as well as of the parental pGPPV clone and the chimeric viruses showing the pGPPV phenotype (Fig. 1B). Such a difference in virus accumulation was not observed in Nicotiana benthamiana control plants that were inoculated and tested simultaneously with the plum seedlings, demonstrating that this difference in genome amplification between parental and chimeric viruses is specific to this Prunus host. These data suggest that the absence of systemic infection in plum could be partially due to a less effective viral genome amplification in the inoculated leaves of plum.

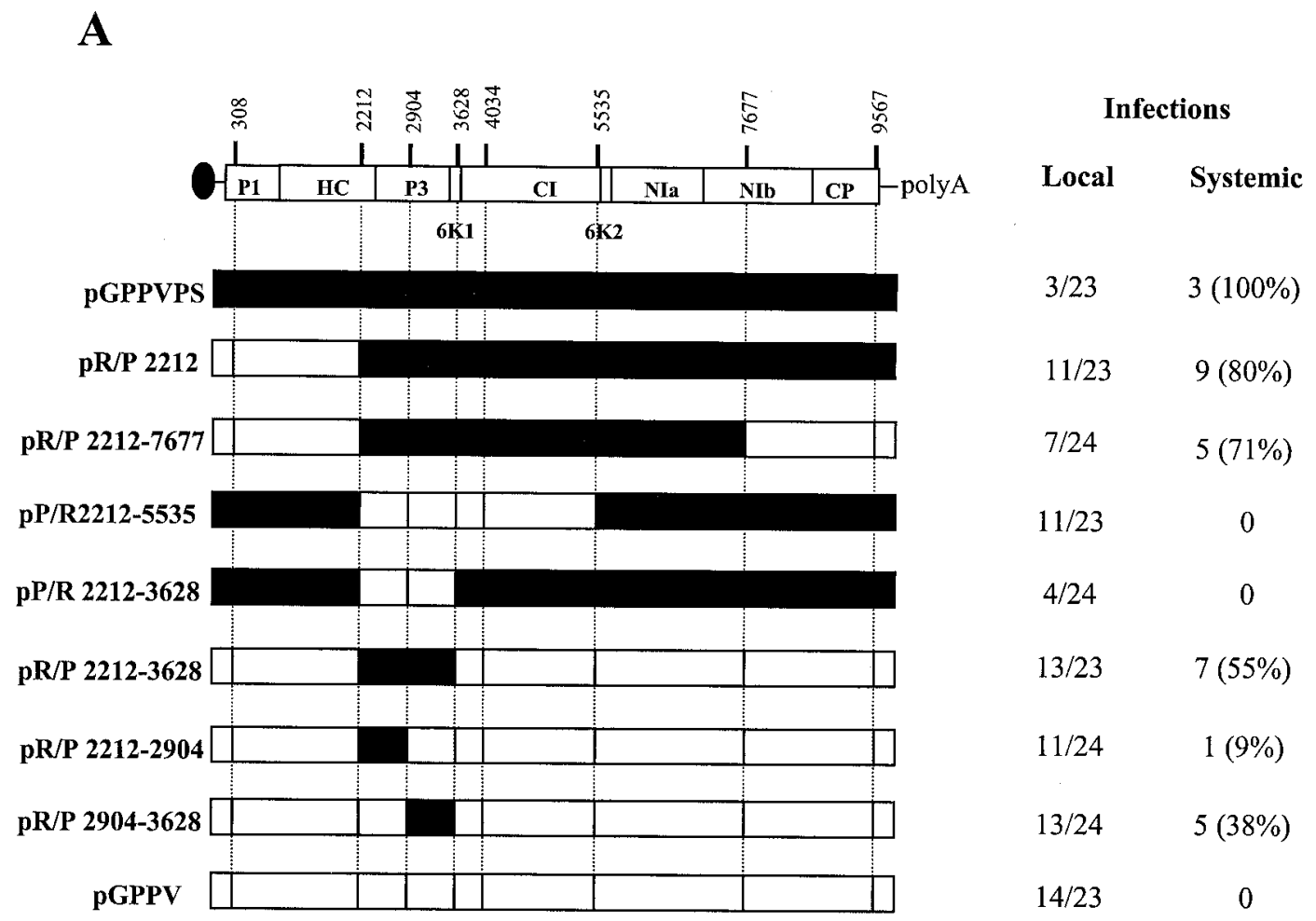

B

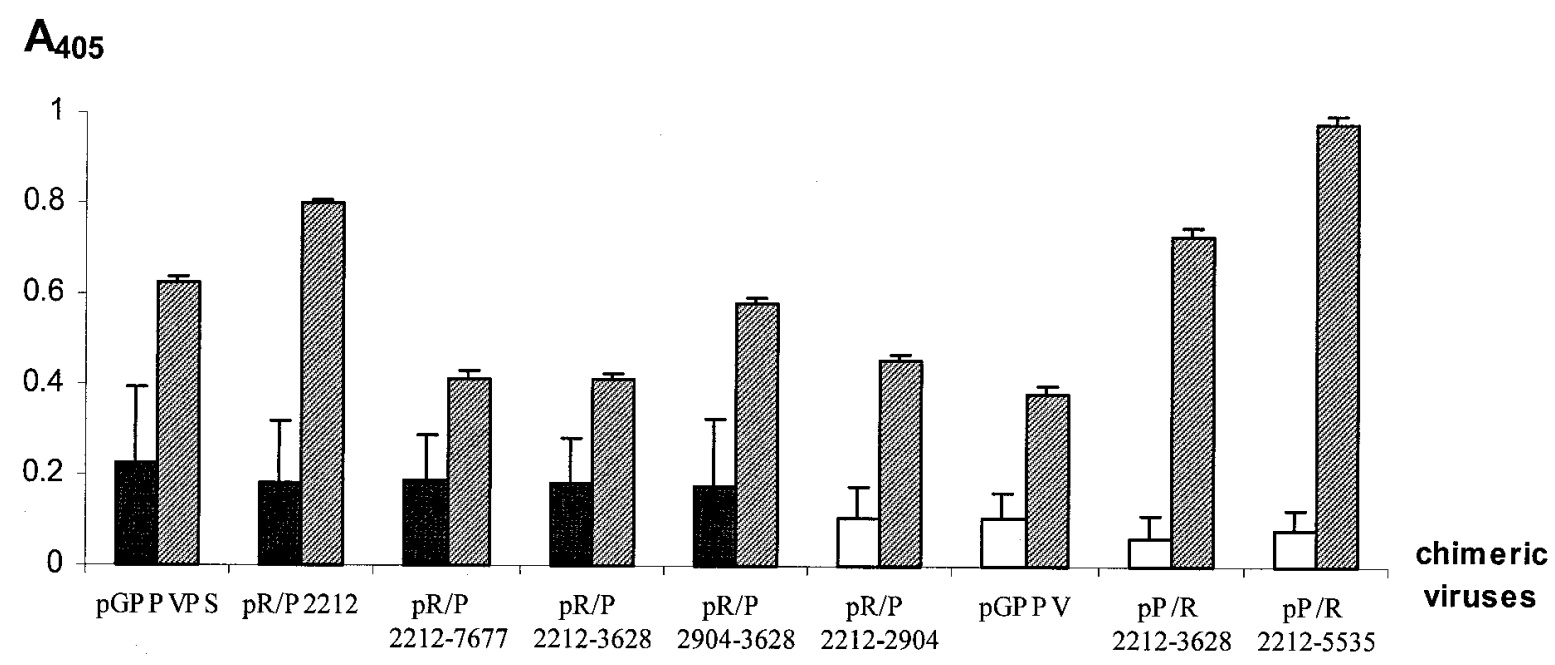

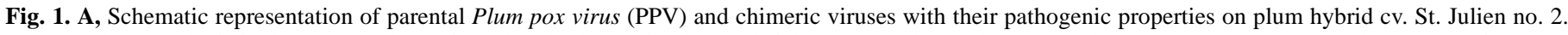

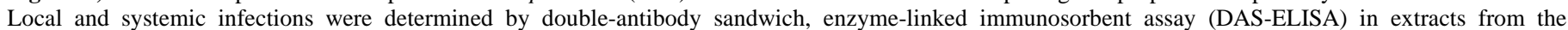

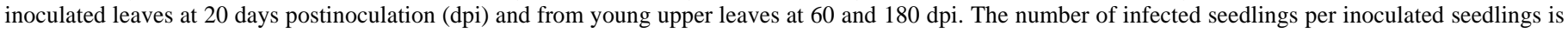

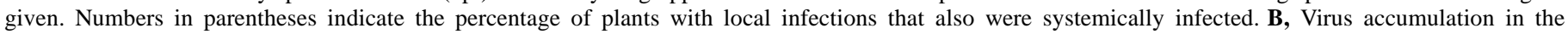

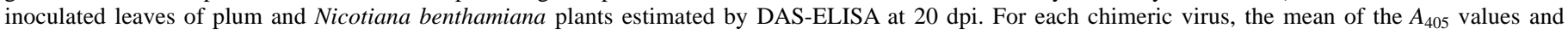

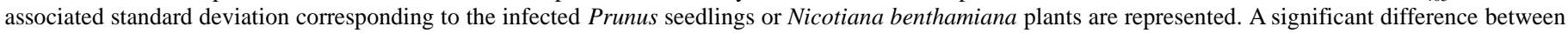

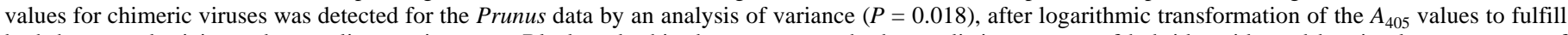

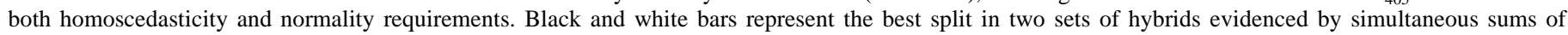
squares test procedure post-hoc tests (33). Such a difference was not observed in Nicotiana benthamiana plants (hatched bars). 
The presence of the pGPPV cylindrical inclusion coding region in the pGPPVPS genome suppresses both local and systemic infection in peach. All chimeric viruses able to infect peach appeared much less capable than the parental pGPPVPS clone of inducing both local and systemic infections (1.6 to $27 \%$ versus $40 \%$ for pGPPVPS; data not shown). In some cases, virus amplification in the inoculated leaves was delayed, leading to under-evaluation of the frequency of local infections at the sampling date (chimera pP/R2212-3628) (Fig. 3).

The introduction of pGPPV fragments, including those encoding P1 and most of $\mathrm{HC}$ alone (pR/P2212) or with partial Nib and CP coding regions (pR/P 2212-7677), into the pGPPVPS genome did not alter the ability of the chimeric viruses to induce both local and systemic infections in peach from that observed for pGPPVPS progeny. This result demonstrates the relevant role of the central region of the PPV genome in these functions (Fig. 3). Using chimeric viruses focused in this region, we were unable however, to more accurately determine the sequences responsible for the pGPPVPS phenotype in peach. In contrast to the results obtained with plum, the introduction of the 2212-3628 pGPPV fragment encoding the P3 and 6K1 proteins into the pGPPVPS genome did not alter the pGPPVPS phenotype (Fig. 3). On the contrary, two chimeric viruses presenting parts of the 2904-3628 pGPPVPS fragment in the pGPPV genome (pR/P2904-3409 and pR/P2904-3628) modified the pGPPV phenotype with the induction of unstable local infections associated with very low virus accumulation (data not shown), highlighting markedly lower viability. These results suggest that this viral genome region is not implicated alone in the phenotypes expressed by the parental clones. By increasing the size of the inserted pGPPV fragments (pP/R2212-4034 and pP/R2212-5535) in the pGPPVPS genome, the capacity of the chimeric viruses to locally and systemically infect this peach cultivar was progressively lost (Fig. 3), highlighting that the cylindrical inclusion (CI) cistron, probably in association with the $\mathrm{P} 3+6 \mathrm{~K} 1$ coding region, has a role in supporting infection by pGPPVPS.

\section{DISCUSSION}

Full-length viral cDNAs, from which infectious transcripts can be obtained and which can be altered to yield chimeric and sitedirected mutant viruses, have been widely used in recent years to better understand potyvirus pathogenesis. Recently, the use of PPV chimeric viruses has led to the identification of viral determinants of specific symptoms in herbaceous hosts (31). To the best of our knowledge, this report contains the first results obtained in Prunus plants, natural woody hosts of this potyvirus. We investigated the determinants of pathogenic properties in peach and plum of two cloned PPV isolates, PPV-PS and PPV-R, previously assigned to the two major molecular and epidemiological groups PPV-M and PPV-D, respectively.

Inoculation procedures and the physiological age of Prunus plants may have a major influence in determining specific hostisolate interactions, as shown by previous studies performed with "natural" PPV isolates $(9,22)$. In contrast to herbaceous plants, long and complex studies are generally required for woody plants due to latency periods and irregular distribution of the virus. Preliminary assays, thus, appeared essential to determine the best experimental conditions, taking into account the woody nature of the host plants and the specific nature of the clones and chimeric viruses. Mechanical inoculation of juvenile Prunus seedlings appeared to be the most efficient method for studying the pathogenic properties of the cloned PPV isolates. However, even in these optimized conditions, the level of infection by the parental clones and chimeric viruses remained low, reaching $50 \%$ in the best cases, in contrast to levels observed in herbaceous hosts (100\%). These results may be partly due to the low pathogenicity of the PPV-R isolate in woody plants, which in turn, could be linked to its longterm maintenance in herbaceous hosts. Nevertheless, this study brings important information to enhance our understanding of PPV pathogenesis in its natural host.

The determinants of PPV pathogenicity were different for plum and peach. In plum, the central region of the PPV genome encod-

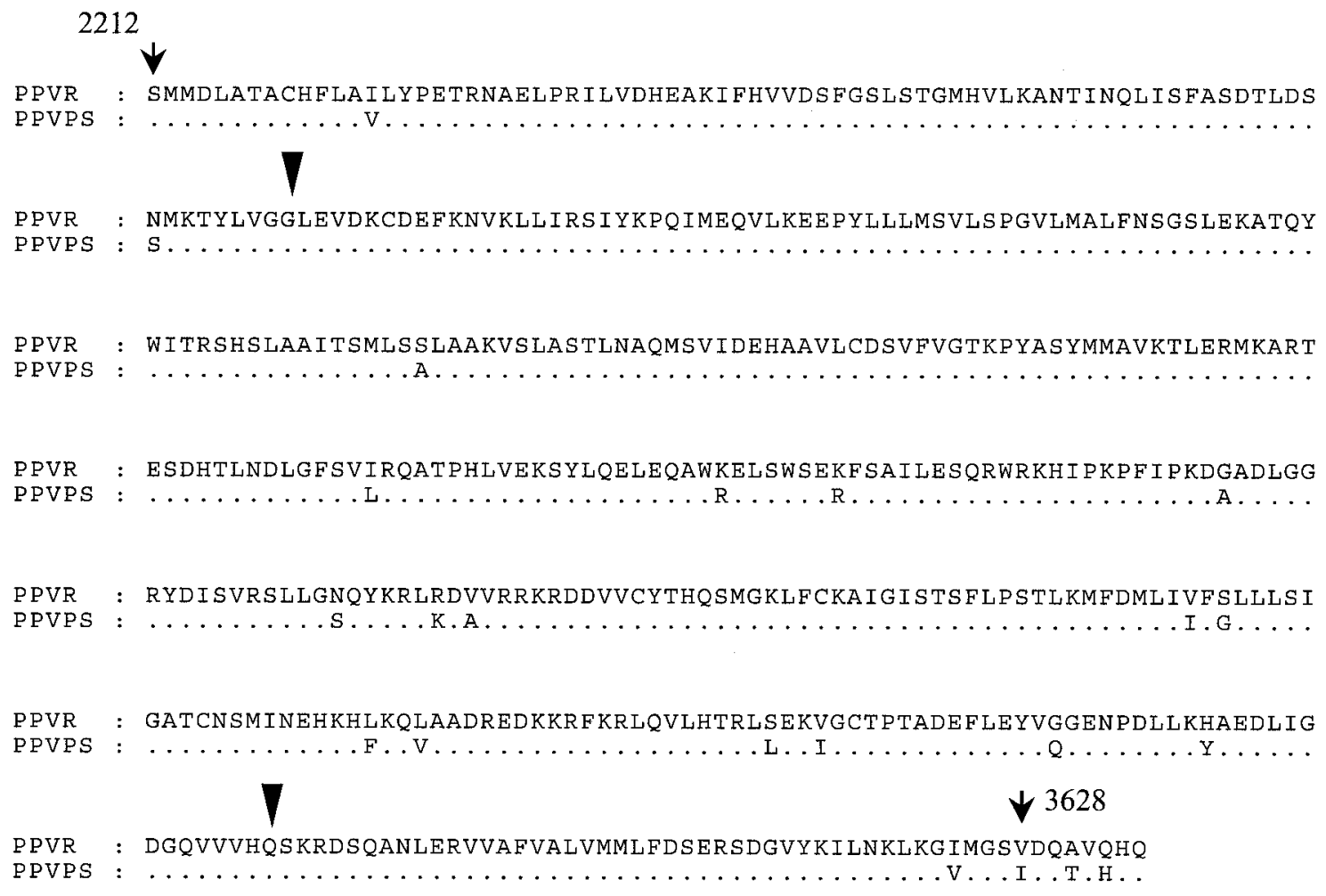

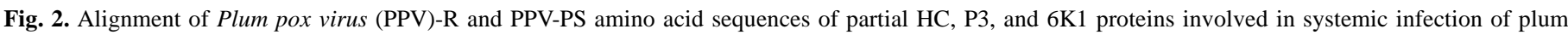

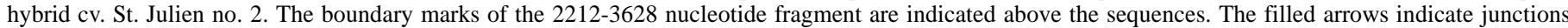
between $\mathrm{HC}$ and $\mathrm{P} 3$ and between $\mathrm{P} 3$ and $6 \mathrm{~K} 1$ proteins. 
ing the C-terminal of the $\mathrm{HC}$, the $\mathrm{P} 3$, and $6 \mathrm{~K} 1$ proteins was responsible for the different phenotypes expressed by the pGPPV and pGPPVPS clones. In peach, the determinant includes the CI protein encoding region. It is quite interesting to note that the involvement of such proteins, alone or in association, in potyvirus pathogenesis has been previously demonstrated for PPV and other potyviruses, especially in symptom induction. The P3 + 6K1 PPV protein was involved in symptom induction in both Nicotiana clevelandii and Pisum sativum (31), whereas the determinants of a wilting response of Tabasco pepper have been located in two separate genomic regions of Tobacco etch virus (TEV), one encompassing the P3 coding region and the other the CI-6K2 and a part of viral genome-linked (VPg)-Nia coding regions (6).

Our results indicate that the viral determinants of systemic infection in plum are located in the genomic region encoding the C-terminal of $\mathrm{HC}$, the $\mathrm{P} 3$, and the N-terminal of the $6 \mathrm{~K} 1$ peptide. Chimeric viruses unable to achieve long-distance movement accumulated, in inoculated plum leaves, at a significantly lower level than the pGPPVPS clone and related hybrids, supporting the hypothesis that the incapacity of pGPPV to induce a systemic infection in this Prunus spp. is at least partially related to its lower replication rate. Colocalization of the $\mathrm{P} 3$ protein with cytoplasmic and nuclear inclusions of Tobacco vein mottling virus (TVMV) and TEV in infected cells $(15,28)$, its in vitro interaction with proteins of the putative replication complex (in particular Nib) of Potato virus A (PVA) (19), as well as, the lethal effect of insertion mutations in the TVMV P3 gene (12) constitute a growing body of evidence that this protein is implicated in the potyvirus replication process. Therefore, differences in the P3 gene or protein between the two PPV isolates (with 16 different amino acids involved in this region) may have some effect on their amplification efficiencies. In addition, several plant virus replication proteins influence cell-to-cell and long-distance movement without necessarily disturbing the replication rate of the virus. Among potyviruses, VPg of TEV in Nicotiana tabacum (32) and of PVA in Nicandra physaloides (23) appears to have a key role in the systemic infection of these hosts. The specific influence of the P3 and 6K1
PPV proteins on cell-to-cell and especially long-distance movement in plum remains to be determined.

The determinants of PPV pathogenicity in peach appeared more complex than in plum. Sequential ELISA tests performed on extracts from mechanically inoculated and new upper leaves of peach cv. GF305 showed that the frequency of local infections was sometimes under-evaluated, probably due to a delay in virus amplification. Similar results were frequently obtained with natural PPV isolates on peach cultivars after aphid inoculations (22). Determinants of pGPPVPS infectivity in peach were situated in the central region of the PPV genome, between the $3^{\prime}$ end of the $\mathrm{HC}$ and the Nib coding regions, but further investigation did not allow us to locate them more accurately. The low infectivity of most hybrids, in comparison with that observed for pGPPVPS, suggests that this property is influenced by multiple determinants located in different parts of the PPV genome. The defective phenotype of pGPPV is probably not the result of interaction with a single gene carried by this host but rather due to a series of incompatible interactions between viral and host factors implicated in genome replication, cell-to-cell movement, and long-distance movement necessary to establish a stable systemic infection. However, the introduction of the pGPPV sequences encoding a part of the $6 \mathrm{~K} 1$ as well as the N-terminal of the CI protein into the pGPPVPS genome was sufficient to restrict PPV infection to inoculated leaves, whereas the presence of the complete pGPPV CI cistron prevented both systemic and local infections. CI protein showing RNA binding and NTPase helicase activities $(11,14,20)$ is required for genome replication $(4,10,12)$, but also for cell-tocell movement of potyviruses $(4,27,29)$. Mutations in TEV CI protein, thus, appeared to prevent cell-to-cell movement in tobacco plants whereas others only limited this property, but in such a way that long-distance movement was impeded (4). Further experimentation is needed to determine if the pGPPV CI cistron alone is sufficient to prevent both local and systemic infection in this peach cultivar and to identify which nucleotide or amino acid is responsible for this phenotype. A comparison of the pGPPV and pGPPVPS CI sequences revealed a difference of 11 amino acids

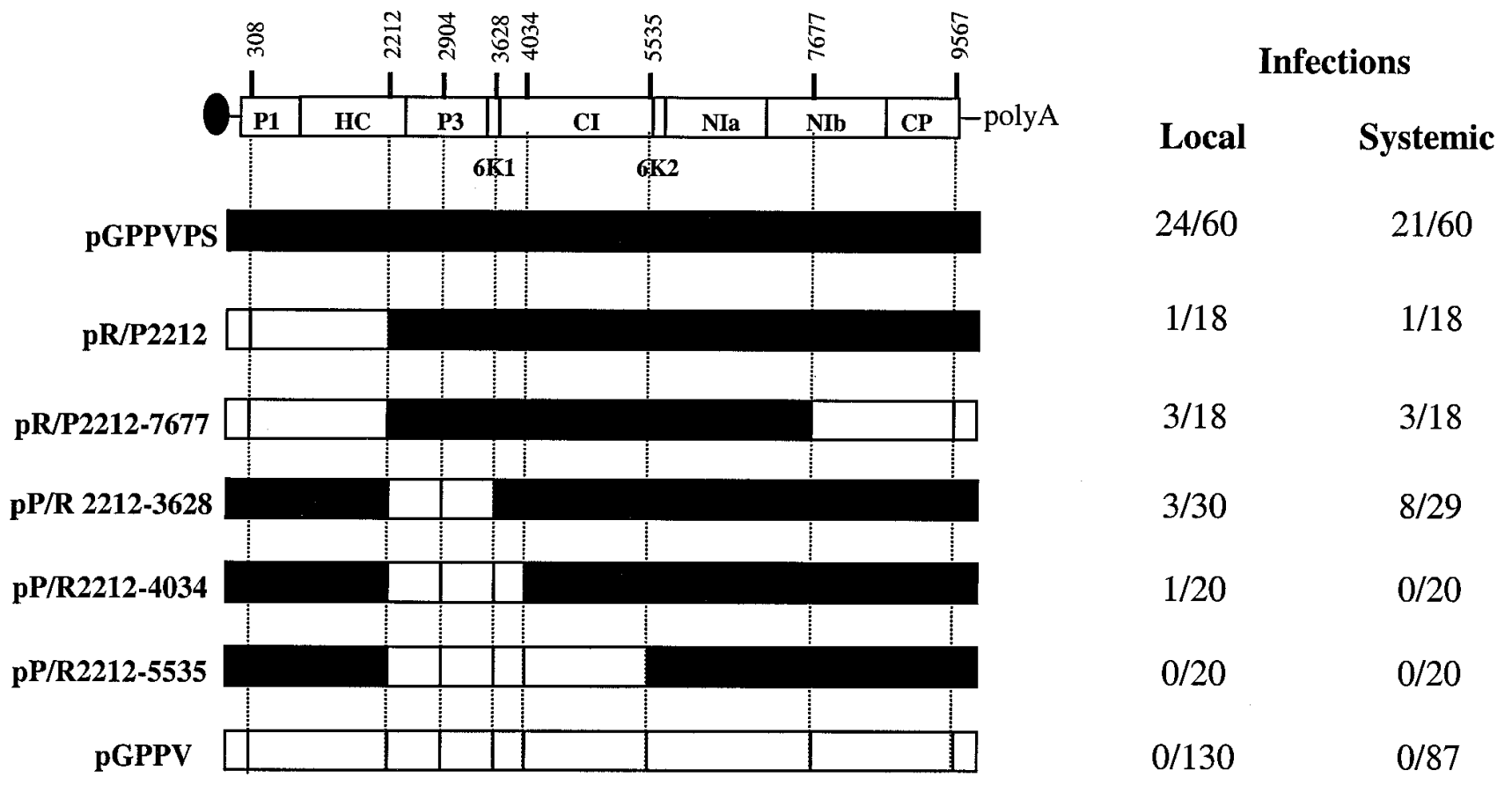

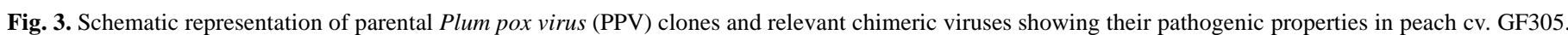

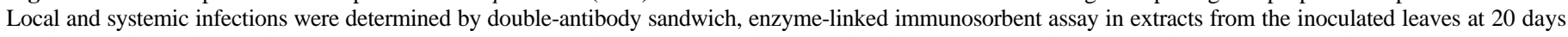

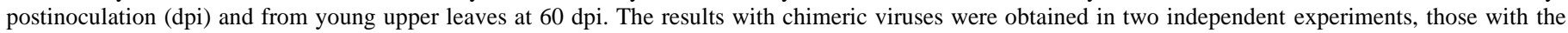
parental viruses in three to four experiments. 
(98\% identity) and a much greater number of nucleotide differences ( $83 \%$ identity).

In plum, as well as in peach, the genomic region encoding the $\mathrm{HC}$ protein and the $\mathrm{CP}$ did not appear to play a relevant role in the observed phenotypes expressed by the PPV clones. Previous studies on different potyviruses have shown the multifunctional properties of both of these proteins, especially in aphid transmission, genome amplification, cell-to-cell movement, and long-distance movements $(1,17,24)$. Our results are interesting because the genomic region encoding the $\mathrm{CP}$ or the $\mathrm{CP}$ itself are currently used to assign PPV isolates into one of the PPV-D or PPV-M molecular groups. This group distinction is of major importance because of the general correlation between it and the ability to infect peach cultivars in orchards $(3,22)$. However, we recently identified peculiar PPV-D isolates in southern France that caused epidemics in peach orchards, similar to those caused by PPV-M isolates, indicating that the classification system may not always be adequate for determining epidemic properties of PPV isolates (9). This study indicates that at least one, and probably numerous others, genomic region is involved in PPV pathogenicity in Prunus spp. The whole of these data may help to improve the design of typing tools, more adequately targeting the pathogenic properties of PPV isolates in cultivated Prunus spp.

\section{ACKNOWLEDGMENTS}

This work was partially supported by a French-Spanish "action intégrée" PICASSO 97-141 and by grants BIO98-0769 from CICYT and BIO-CT97-2300 and 2356 from the Biotechnology Program of the European Union. We thank M. Boeglin and E. Domínguez for technical participation, S. Dallot for statistical analysis, M. Bousalem for fruitful comments on the manuscript prior to submission, and R. Nelson for comments and suggestions for improving the manuscript.

\section{LITERATURE CITED}

1. Andrejeva, J., Puurand, Ü., Merits, A., Rabenstein, F., Järvekülg, L., and Valkonen, J. P. T. 1999. Potyvirus helper component-proteinase and coat protein $(\mathrm{CP})$ have coordinated functions in virus-host interactions and the same CP motif affects virus transmission and accumulation. J. Gen. Virol. 80:1133-1139.

2. Bousalem, M., Candresse, T., Quiot-Douine, L., and Quiot, J. B. 1994. Comparison of three methods for assessing plum pox virus variability: Further evidence for the existence of two major groups of isolates. J. Phytopathol. 142:163-172.

3. Candresse, T., Cambra, M., Dallot, S., Lanneau, M., Asensio, M., Gorris, M. T., Revers, F., Macquaire, G., Olmos, A., Boscia, D., Quiot, J. B., and Dunez, J. 1998. Comparison of monoclonal antibodies and polymerase chain reaction assays for the typing of isolates belonging to the $\mathrm{D}$ and $\mathrm{M}$ serotypes of plum pox potyvirus. Phytopathology 88:198-204.

4. Carrington, J. C., Jensen, P. E., and Schaad, M. C. 1998. Genetic evidence for an essential role for potyvirus CI protein in cell-to-cell movement. Plant J. 14:393-400.

5. Cervera, M. T., Riechmann, J. L., Martín, M. T., and García, J. A. 1993. 3' Terminal sequence of the plum pox virus PS and O6 isolates: Evidence for RNA recombination within the potyvirus group. J. Gen. Virol. 74:329-334.

6. Chu, M., Lopez-Moya, J. J., Llave-Correas, C., and Pirone, T. P. 1997. Two separate regions in the genome of the tobacco etch virus contain determinants of the wilting response of Tabasco pepper. Mol. Plant-Microbe Interact. 10:472-480.

7. Clark, M. F., and Adams, A. N. 1977. Characteristics of the microplate method of enzyme-linked immunosorbent assay for the detection of plant viruses. J. Gen. Virol. 34:475-483.

8. Crescenzi, A., d'Aquino, L., Comes, S., Nuzzaci, M., Piazolla, P., Boscia, D., and Hadidi, A. 1997. Characterization of the sweet cherry isolate of plum pox potyvirus. Plant Dis. 81:711-714.

9. Dallot, S., Labonne, G., Quiot-douine, L., Boeglin, M., Candresse, T., and Quiot, J. B. 1998. Peculiar plum pox potyvirus D-populations are epidemic in peach trees. Acta Hortic. 472:355-365.

10. Fernández, A., Guo, H. S., Sáenz, P., Simón-Buela, L., Gómez de Cedrón, M., and García, J. A. 1997. The motif V of plum pox potyvirus CI
RNA helicase is involved in NTP hydrolysis and is essential for virus replication. Nucleic Acids Res. 25:4474-4480.

11. Fernández, A., Laín, S., and García, J. A. 1995. RNA-helicase activity of the plum pox potyvirus CI protein expressed in Escherichia coli. Mapping of an RNA binding domain. Nucleic Acids Res. 23:1327-1332.

12. Klein, P. G., Klein, R. R., Rodríguez-Cerezo, E., Hunt, A. G., and Shaw, J. G. 1994. Mutational analysis of the tobacco vein mottling virus genome. Virology 204:759-769.

13. Laín, S., Riechmann, J. L., and García, J. A. 1989. The complete nucleotide sequence of plum pox potyvirus RNA. Virus Res. 13:157-172.

14. Laín, S., Riechmann, J. L., and García, A. 1990. RNA helicase novel activity associated with a protein encoded by a positive strand RNA virus. Nucleic Acids Res. 18:7003-7006.

15. Langenberg, W. G., and Zhang, L. 1997. Immunocytology shows the presence of tobacco etch virus P3 protein in nuclear inclusions. J. Struc. Biol. 118:243-247.

16. Levy, L., Dansteegt, V., and Welliver, R. 2000. First report of Plum pox virus (Sharka disease) in Prunus persica in the United States. Plant Dis. 84:202.

17. Maia, I. G., Haenni, A. L., and Bernardi, F. 1996. Potyviral HC-pro: A multifunctional protein. J. Gen. Virol. 77:1335-1341.

18. Maiss, E., Timpe, U., Brisske-Rode, A., Leesemann, D. E., and Casper, R. 1992. Infectious in vivo transcripts of a plum pox potyvirus fulllength cDNA clone containing the cauliflower mosaic virus 35S RNA promoter. J. Gen. Virol. 73:709-713.

19. Merits, A., Guo, D., Järvekülg, L., and Saarma, M. 1999. Biochemical and genetic evidence for interactions between potato A potyvirus-encoded proteins P1 and P3 and proteins of the putative replication complex. Virology 263:15-22.

20. Merits, A., Guo, D., and Saarma, M. 1998. VPg, coat protein and five non-structural proteins of potato A potyvirus bind RNA in a sequenceunspecific manner. J. Gen. Virol. 79:3123-3127.

21. Nemchinov, L., and Hadidi, A. 1996. Characterization of the sour cherry strain of plum pox virus. Phytopathology 86:575-580.

22. Quiot, J. B., Labonne, G., Boeglin, M., Adamolle, C., Renaud, L. Y., and Candresse, T. 1995. Behavior of two isolates of plum pox virus inoculated on peach and apricot trees: First results. Acta Hortic. 386:290-297.

23. Rajamäki, M.-L., and Valkonen, J. P. T. 1999. The 6K2 protein and the VPg of potato virus A are determinants of systemic infection in Nicandra physaloides. Mol. Plant-Microbe Interact. 12:1074-1081.

24. Revers, F., Le Gall, O., Candresse, T., and Maule, A. J. 1999. New advances in understanding the molecular biology of plant/potyvirus interactions. Mol. Plant-Microbe Interact. 12:367-376.

25. Riechmann, J. L., Laín, S., and García, J. A. 1990. Infectious in vitro transcripts from a plum pox potyvirus cDNA clone. Virology 177:710716.

26. Riechmann, J. L., Laín, S., and García, J. A. 1992. Highlights and prospects of potyvirus molecular biology. J. Gen. Virol. 73:1-16.

27. Roberts, I. M., Wang, D., Findlay, K., and Maule, A. J. 1998. Ultrastructural and temporal observations of the potyvirus cylindrical inclusions (CIs) show that the CI protein acts transiently in aiding virus movement. Virology 245:173-181.

28. Rodríguez-Cerezo, E., Ammar, E. D., Pirone, T. P., and Shaw, J. G. 1993. Association of the non-structural P3 viral protein with cylindrical inclusions in potyvirus-infected cells. J. Gen. Virol. 74:1945-1949.

29. Rodríguez-Cerezo, E., Findlay, K., Shaw, J. G., Lomonossoff, G. P., Qiu, S. G., Linstead, P., Shanks, M., and Risco, C. 1997. The coat and cylindrical inclusion proteins of a potyvirus are associated with connections between plant cells. Virology 236:296-306.

30. Roy, A. S., and Smith, I. M. 1994. Plum pox situation in Europe. Eur. Mediter. Plant Prot. Organ. Bull. 24:515-523.

31. Sáenz, P., Cervera, M. T., Dallot, S., Quiot, L., Quiot, J. B., Riechmann, J. L., and Garcia, J. A. 2000. Identification of a pathogenicity determinant of Plum pox virus in the sequence encoding the C-terminal region of protein P3+6K1. J. Gen. Virol. 81:557-566.

32. Schaad, M. C., Lellis, A. D., and Carrington, J. C. 1997. VPg of tobacco etch potyvirus is a host genotype-specific determinant for long distance movement. J. Virol. 71:8624-8631.

33. Sokal, R. R., and Rohlf, F. J. 1981. Biometry. 2nd ed. W. H. Freeman \& Co., San Francisco.

34. Wetzel, T., Candresse, T., Macquaire, G., Ravelonandro, M., and Dunez, J. 1992. A highly sensitive immunocapture polymerase chain reaction method for plum pox potyvirus detection. J. Virol. Methods 39:27-37.

35. Wetzel, T., Candresse, T., Ravelonandro, M., Delbos, R. P., Mazyad, H., Aboul-Ata, A. E., and Dunez, J. 1991. Nucleotide sequence of the 3'terminal region of the RNA of the El Amar strain of plum pox potyvirus. J. Gen. Virol. 72:1741-1746. 